\title{
The Investigation of Critical Thinking Disposition among Kasetsart University Students
}

\author{
Jittinun Boonsathirakul ${ }^{1} \&$ Chakree Kerdsomboon $^{1}$ \\ ${ }^{1}$ Faculty of Education, Kasetsart University, Bangkok, Thailand \\ Correspondence: Jittinun Boonsathirakul, Faculty of Education, Kasetsart University, Bangkok, Thailand. Tel: \\ 66-979-892-991. E-mail: fedujnb@ku.ac.th
}

Received: March 30, 2021

doi:10.5539/hes.v11n2p224
Accepted: April 30, $2021 \quad$ Online Published: May 6, 2021

URL: https://doi.org/10.5539/hes.v11n2p224

\begin{abstract}
This research study aims to investigate university student's critical thinking disposition (CTD). The sample includes 633 undergraduate students at different levels from Kasetsart University, Thailand. The analysis was based on convenience random sampling. The CTD instrument comprises 24 Likert scale. The subscales consisted of seven crucial dimensions: truth-seeking, open-mindedness, analyticity, systematicity, critical thinking self-confidence, inquisitiveness, and cognitive maturity. The cumulative percent of variance was $61.84 \%$. Cronbrach's alpha for the overall instrument, the disposition toward critical thinking was .78. The findings revealed that critical thinking disposition has no distinctive correlation to significant difference towards gender and the different levels of university students significantly, particularly at the level of $\mathrm{p}<.05$.
\end{abstract}

Keywords: critical thinking disposition, undergraduate students, university students

\section{Introduction}

Nowadays, we are in the mainstream of the information society that is dynamically emerged and rapidly expanded to the major masses. Moreover, the emergence of general information is considerably one of the most crucial phenomena that affect individuals inevitably. In the midst of these dynamically change society the students are therefore required to adopt these skills in order to stimulate social awareness and contribute to society (Ghadi et al., 2012). Also, individuals are expected and encouraged to acquire that knowledge simultaneously in order to obtain innovative knowledge within the scattered information, to examine those knowledges to resolve everyday life problems, and to transform it into products (Boyaci \& Atalay, 2016). For this reason, an individual should possess high level skills such as analytical thinking and organization of knowledge (Tiruneh et al., 2014; Velez, 2012).

In history, critical thinking was the significant components of human resource development (Boyaci \& Atalay, 2016). Currently, conducting research studies and structuring the information with critical thinking skills are potentially concentrated, individuals are expected to resolve the problems with intellectual knowledge and practical experiences. Shute \& Becker (2010) defined that the required skills of individuals in the $21^{\text {st }}$ Century are rather different comparing to the previous era; primarily on the emergence of advanced information and communication technologies.

Generally, students are acknowledged as one of the most essential human resources in every country; the methods of critical thinking are necessarily developed in order that it could be applied to academic research studies, problem resolutions, and critical decision-makings.

For this reason, university has become a leading mechanism and played an important role to enhancing awareness, cultivating intellectual skills, developing beneficial skills, and improving efficient thought skills. As a result, the roles of educational institutes have transformed to the center of information sources. Meanwhile, the roles of professors as the information transferor are needed to be adjusted. The students are advised to improve their rational and mental skills with intellectual analysis and processing (Bagheri \& Nowrozi, 2015). Critical thinking refers to the ability of a person to consider and analyze information or situations systematically and logically. Base on their intelligences and experiences in exploring evidences, it could possibly be led to reasonable and intelligent conclusions (Bodi, 1988). To support this notion, Facione (2000) defined that critical thinking is the capability to think rationally and comprehensibly that focuses on making a decision what to do or 
what to believe. Walker (2003) affirmed that to develop critical thinking, one must possess and use specific critical thinking disposition. Walker's statement was completed by Facione et al. (1995) which explained that someone who thinks critically uses seven dispositions to shape and make decisions namely truth-seeking, open-mindedness, analyticity, systematicity, critical thinking self-confidence, inquisitiveness, and cognitive maturity.

The development of critical thinking is generally acquiescent as a key aim of higher education (Moore, 2013). Several studies demonstrate that students develop critical thinking abilities during college period (Gelling, 20003; Giancarlo, 2001). Furthermore, Bagheri \& Nowrozi (2015) also support that the professors should strengthen critical thinking skills to students to enable them to make decisions on a well-thought judgment upon the available information.

According to Ennis (1996); Halpem (1998), Educational researchers and theorists place that any conceptualization of critical thinking must include both skills and dispositions. Poondej \& Lerdpornkulrat (2015) also state that assessing the disposition dimension of CT has gained more importance than assessing the cognitive skills dimension. Further, the motivational theory of Lewin (1935) presents the theoretical framework for the assumption that the disposition to value and employ critical thinking would drive an individual to lead mastery over critical thinking skills.

The purposes of this study aim to investigate critical thinking disposition of Thai university student as follows:

1) Is there any significant difference in critical thinking disposition of the participants related to gender?

2) Is there any significant difference in critical thinking disposition consistent with the different levels of university students?

\section{Literature Review}

\subsection{The Concept of Critical Thinking Disposition}

Many conceptions of critical thinking disposition have been projected. For instance, Beyer (1985) identified critical thinking disposition as a frame of mind and mental operations that included alertness to the need to evaluate information, a willingness to test opinions, and a desire of considering all viewpoints. Siegel (1988) also defined critical thinking disposition as having a critical spirit that included intellectual honesty, impartiality, objectivity, justice to evidence, commitment to seek and evaluate reasons. APA committee proposed the concept of critical thinking disposition in a positive manifestation sense as characterized truth-seeking, open-mindedness, analyticity, systematicity, self-confidence, inquisitiveness, and maturity (Facione, 1990).

\subsection{The Instruments for Measuring Critical Thinking Disposition}

Little are known of approval on assessing critical thinking dispositions, and only few instruments are designed for measuring critical thinking dispositions. One of the most widely acknowledged critical thinking disposition scales is the California Critical Thinking Disposition Inventory (CCTDI) developed by Facione and Facione (1992). The CCTDI based on the Delphi Report's consensus definition of a critical thinker (Facione, 1990) focuses on the effective, attitudinal dimension. Followed by factor and item analysis techniques, seven affective components of overall CCTDI, were created as follows: truth-seeking, open-mindedness, analyticity, systematicity, inquisitiveness, self-confidence, and maturity.

\subsection{Critical Thinking Dispositions among Undergraduate Students}

Critical thinking (CT) is a conceptual notion that deliberated an individual's traits, characteristics traits, or manners of the mind (Facione, 1990). It was common about the perception that human beings could improve and correct themselves. With clear reference to management and skills to understand that what the authentic was, what one should believe, why that was and how it occurred. Critical thinking is the competence to apply higher levels of thinking skills (concept formulation, analysis, assessment) and management to consider about thinking (being broad-minded or always seeking the truth regardless of whether or not one agreed with one's own personal beliefs) that pointed to rational and proper action (Papp et al., 2014). It was unanimity that the nature of critical thinking was a process of self-improvement in order to decide what to believe and what to do in different situations (Facione et al., 1994). The person's inherent qualities of mind and character towards CT was related to the skills of problem - solving and decision - making that facilitated thinking. The disposition is a characteristic that must be continuously accumulated (Khemmani, 2011).

From the mentioned statement, it reflected that CT disposition was considerably significant to the undergraduate students. Furthermore, in most countries including Thailand, undergraduate students were encouraged to practice decision-making and problem-solving by themselves such as educational challenges, interpersonal and relation 
affairs, and so on (Niyomtham at el., 2017; Khempet, 2018). As a result, a number of unskilled students were forced to discontinue their education when encountering both internal and external difficulties. Whereas, some competent and well-developed students acquiring those skills had a tendency in self-improvement effectively, it leaded to the reduction of dropping - out rate (Lazarus \& Folkman, 1984).

Sirichat (2007) conducted research on a study of critical thinking at Chiang Mai University with 395 undergraduate Thai students. It was found that male and female Thai students had no significantly difference in the aspect of critical thinking. Relevant to Poondej's research (2012) which conducted a study of 1336 students studying in multiple Thai programs. Moreover, Wangensteen et al. (2010) studied critical thinking characteristics among 618 newly graduated Thai nurses. A majority of the Thai research studies revealed that student's gender might not be an influential factor to critical thinking characteristics. Also, Sirichat's study (2007) defined that Thai students with distinctive academic achievement tended to demonstrate similar critical thinking characteristics. Taskesen (2019) studied on students in the Faculty of Education in Turkey, it was found that there was no remarkable difference in critical thinking disposition among 1st to 4th year undergraduate Turkish students, and gender might not be related to critical thinking disposition. Abiogu et al., (2020) investigated critical thinking disposition of undergraduate nursing students, it was found that there was no significant difference among undergraduate nursing students.

However, it was possibly inconsistent with the Facione et al.'s (2001), who studied on critical thinking characteristics and academic performance. Meanwhile, Klaharn (2014) demonstrated that some student acquiring advantaged or disadvantaged academic performance had the possibility to be caused by unidentified factors rather than their indigenous knowledge background. For example, motivation for achievement, discipline and responsibility, environment, and also teacher's teaching quality.

In addition, Facione et al., (2001) studied on critical thinking traits more than 4 years with undergraduate students, it was found that the related possibility between higher academic year tended to develop higher critical thinking. This was a positive congruent with the research of Sirichat's (2007) studying on Thai students in distinctive levels, it revealed that the varied academic years probably generated an important influence on critical thinking habits, to illustrate this, the higher level of Thai students were likely to possess higher critical thinking. This was assured by statistically significant differences in critical thinking habits at the .05 level. Furthermore, it was also consistent with the Lampert's study (2006) who discovered that the higher year students seemed to acquire higher critical thinking characteristics than the first - year students. Wang et al., (2019) developed the critical thinking disposition inventory for Chinese medical college students, it was found that gender, age, and education level significantly predicted the critical thinking disposition.

Further, Sirichat's study (2007) also found that the mean score of critical thinking habits of Thai people was probably underneath the standard used as a criterion (cut score) of Facione and Facione (1992). This was consistent with the Yah and Chen (2003) studying of the critical thinking traits between Chinese and American nursing students, it was found that American students delivered higher score than Chinese students. This result supported that distinctive cultures have probably varied the aspect of critical thinking (Ip et al, 2000). This might be the result of cultural traits affecting the characteristics of critical thinking. In other words, A majority of Westerners have possessed an individualistic thinking approach (individualism), whereas, most Asians have rather dominated a collective social model (Collectivism) (Voronov \& Singer, 2002).

\section{Method}

\subsection{Participants \& Sampling}

The participants of this research include 633 undergraduate students in the second semester, the academic year 2018, at Kasetsart University, Bangkhen campus, Thailand. In this research, the proportions of participants were $286(45.2 \%)$ male and $347(54.8 \%)$ female respectively. Among them, $178(28.1 \%)$ were freshmen, $164(25.9 \%)$ sophomore, 154 (24.3\%) junior, and 137 (21.7\%) senior. The sample varied of demographic factors, as show in Table 1. 
Table 1 . The summary of sample demography $(\mathrm{N}=633)$

\begin{tabular}{llll}
\hline \multirow{2}{*}{ Background } & \multicolumn{2}{l}{ Subtotal } \\
\cline { 3 - 4 } & & $\mathrm{n}$ & $\%$ \\
\hline Gender & Male & 286 & 45.2 \\
& Female & 347 & 54.8 \\
Level & Freshmen & 178 & 28.1 \\
& Sophomore & 164 & 25.9 \\
& Junior & 154 & 24.3 \\
& Senior & 137 & 21.7 \\
Total & & 633 & 100.0 \\
\hline
\end{tabular}

\subsection{Instrument}

The instrument used in this study was the Critical Thinking Disposition Questionnaire (CTD) which consisted of the seven factors derived and modified from the previous literatures. The CTD questionnaire consisted of 24 items to measure seven dimensions. Table 2 demonstrates the dimensions of CTD questionnaire. Three respective experts in educational psychology were invited to be content validator. Each expert was provided with a set of three documents consisting of content domains, the CTD questionnaire, and the content validity estimation scale.

Table 2. The dimensions of Critical Thinking Disposition Questionnaire

\begin{tabular}{|c|c|}
\hline Dimension & Description \\
\hline Truth-seeking & $\begin{array}{l}\text { Targets honesty and objectivity with findings, even if the findings do not } \\
\text { support one's self-interests or preconceived opinions. }\end{array}$ \\
\hline Open-mindedness & $\begin{array}{l}\text { Addresses being tolerant of divergent views with sensitivity to the possibility } \\
\text { of one's own bias. }\end{array}$ \\
\hline Analyticity & Targets are prizing the use of reason and evidence to resolve problems. \\
\hline Systematicity & $\begin{array}{l}\text { Measures the tendency toward the use of an organized, orderly, focused, } \\
\text { and diligent process in the inquiry stage. }\end{array}$ \\
\hline Critical thinking Self-confidence & Measures the trust one places in one's own reasoning processes. \\
\hline Inquisitiveness & $\begin{array}{l}\text { Measures one's intellectual curiosity and desire for learning, even when the } \\
\text { application of the knowledge is not readily apparent. }\end{array}$ \\
\hline Cognitive maturity & Targets the disposition to be judicious (prudent) in one's decision making. \\
\hline
\end{tabular}

The construct validities and reliabilities of the CTD questionnaire are also determined in Table 3. The factor loading for the CTD questionnaire designed to measure each factor were between .47 and .76 . The total variance explained by the seven subscales was $61.84 \%$ Likert rating scale was employed to investigate the participants' perception ranging from "Strongly Disagree, Disagree, Partly Disagree, Partly Agree, Agree, and Strongly Agree." respectively. The higher score reflects stronger the overall disposition towards critical thinking.

\subsection{Analytic strategy}

The means and standard deviations were calculated to investigate the relevance between male and female. An independent t-test was employed to test the differences towards gender. Further, the analysis of variances was utilized to examine the differences of critical thinking disposition among levels of students.

\section{Results and Discussion}

\subsection{Exploratory Factor Analysis of CTD Questionnaire}

A process of factor analysis, the initial series of factor collections is acquired by utilizing a systematic approach that permits convenient calculation of the collections (Crocker \& Algina, 1986). For CTD questionnaire (Table 3 ), the factors were classified into 7 aspects with 24 items under the procedure of conducting exploratory factor analysis with varimax rotation, checking eigenvalue, loading factor, and following by analyzing of internal consistency of factor structure. The Kaiser-Meyer-Olkin (KMO) value was .81 and the result of Bartlett's Chi-Square test $\left(X^{2}=1511.59, \mathrm{df}=276, \mathrm{p}<.001\right)$, demonstrating that the samples were properly suitable for factor analysis. Table 3 also presents the validity and reliability assurance of the critical thinking disposition questionnaire. The overall seven factors were distinctively illustrated at $61.84 \%$ of the total variance. Each factor collection arranged to calculate critical thinking disposition was between .46 to .76 , with Cronbach's a 
coefficients for these factors were $.50, .51, .57, .80, .76, .65$, and .65 , respectively, and the overall alpha value was .78 .

Table 3. The validity and reliability assurance of the Critical Thinking Disposition Questionnaire

\begin{tabular}{|c|c|c|c|c|}
\hline Factor & Item & $\lambda$ & $\%$ & $\alpha$ \\
\hline \multirow{3}{*}{ Truth-seeking } & 1. I prefer passive learning more than active learning. & .70 & 13.94 & .50 \\
\hline & $\begin{array}{l}\text { 2. I like to work on the capabilities and available } \\
\text { information without much effort. }\end{array}$ & .54 & & \\
\hline & 3. I am constantly researching to learn new things & .57 & & \\
\hline \multirow[t]{4}{*}{ Open-mindedness } & $\begin{array}{l}\text { 4. If someone does not like my idea even one person, } \\
\text { I will not comment anymore. }\end{array}$ & .57 & 12.28 & .51 \\
\hline & 5. I don't like to hear the opinions of others. & .47 & & \\
\hline & $\begin{array}{l}\text { 6. One of my mistake in making a decision is because } \\
\text { I do not listen to other people's oninions }\end{array}$ & .56 & & \\
\hline & $\begin{array}{l}\text { 7. I think we should not accept people who } \\
\text { repeatedly make mistakes. }\end{array}$ & .70 & & \\
\hline \multirow[t]{3}{*}{ Analyticity } & $\begin{array}{l}\text { 8. If there is a conflict, I chose to take side with the } \\
\text { more rational people. }\end{array}$ & .75 & 8.26 & .57 \\
\hline & $\begin{array}{l}\text { 9. I always evaluate the argument of others, } \\
\text { whether there are sufficient reasons. }\end{array}$ & .46 & & \\
\hline & 10. Everything I believe must be rational and reliable. & .66 & & \\
\hline \multirow[t]{3}{*}{ Systematicity } & $\begin{array}{l}\text { 11. I plan well before I do any work. } \\
\text { 12. In my work, I usually organize my thinking } \\
\text { system in a step-by-step manner. }\end{array}$ & $\begin{array}{l}.70 \\
.76\end{array}$ & 7.95 & .80 \\
\hline & $\begin{array}{l}\text { 13. I am described as having an orderly and systematic } \\
\text { procedure towards complex problems }\end{array}$ & .58 & & \\
\hline & 14. I can plan step by step to solve complex problems. & .64 & & \\
\hline \multirow[t]{4}{*}{$\begin{array}{l}\text { Critical thinking } \\
\text { Self-confidence }\end{array}$} & $\begin{array}{l}\text { 15. My friends always make me decide on the situation } \\
\text { because my friends think that I judge justice. }\end{array}$ & .57 & 7.37 & .76 \\
\hline & 16. People admire my desire for knowledge and learning. & .64 & & \\
\hline & $\begin{array}{l}\text { 17. I am proud of myself that I can find alternatives } \\
\text { way to solve the problem. }\end{array}$ & .61 & & \\
\hline & $\begin{array}{l}\text { 18. My friends expect me to offer new approaches } \\
\text { for use in the complex and complicated task. }\end{array}$ & .69 & & \\
\hline \multirow[t]{3}{*}{ Inquisitiveness } & 19. I am eager to learn what I am interested in. & .55 & 6.83 & .65 \\
\hline & 20. I am happy to learn everything around me. & .70 & & \\
\hline & 21. I enjoy solving complex problems. & .55 & & \\
\hline \multirow{3}{*}{$\begin{array}{l}\text { Cognitive } \\
\text { maturity }\end{array}$} & 22. If I can choose, I will not choose to make any decision. & .54 & 5.21 & .65 \\
\hline & 23. I feel uneasy whenever I have to choose something. & .66 & & \\
\hline & 24. Sometimes I feel I do not know how to decide. & .68 & & \\
\hline Overall & & & 61.84 & .78 \\
\hline
\end{tabular}

\subsection{Critical Thinking Disposition}

Table 4 summarizes the results of the t-test for independent samples in order to respond to the research problem that there is any significant difference in critical thinking disposition of the participants related to gender.

According to Table 4 , the result illustrates narrow gap between the mean scores of female $(M=4.11)$ and male $(M=4.19)$. However, at the level of $p<.05$, no significant difference was particularly found, these proved that there is no significant difference in critical thinking towards gender. The findings of this study are correlation to the previous findings of Demirbag et al. (2016); that is, there is no difference in critical thinking disposition total scores between male and female. 
Table 4. Summary of independent t-test by gender

\begin{tabular}{llllll}
\hline & \multicolumn{4}{l}{ Male $(\mathrm{n}=286)$} & \multicolumn{4}{l}{ Female $(\mathrm{n}=344)$} \\
\hline Dimension & $\mathrm{M}$ & $\mathrm{SD}$ & $\mathrm{M}$ & $\mathrm{SD}$ & $\mathrm{t}$ \\
\hline Truth seeking & 4.02 & .87 & 4.01 & .76 & .12 \\
Open mindedness & 4.05 & .89 & 4.42 & .75 & -3.20 \\
Analyticity & 4.64 & .80 & 4.34 & .69 & 2.96 \\
Systematicity & 4.65 & .72 & 4.33 & .76 & 3.07 \\
Critical thinking Self-confidence & 4.15 & .87 & 3.94 & .80 & 1.78 \\
Inquisitiveness & 4.67 & .79 & 4.51 & .75 & 1.44 \\
Cognitive maturity & 3.06 & .93 & 3.07 & .97 & -0.41 \\
Total & 4.19 & .46 & 4.11 & .44 & 1.37 \\
\hline
\end{tabular}

According to Table 5, it shows that the different levels at university are disconnected with critical thinking disposition significantly. The mean scores of the sophomore and senior $(M=4.20)$ is higher than the freshmen $(\mathrm{M}=4.13)$ and junior $(\mathrm{M}=4.06)$ respectively. Moreover, there is no significant difference at the level of $\mathrm{p}<.05$. In response to the research problem, it concludes that there is no significant difference in critical thinking disposition consistent with the different levels of university students.

Table 5. Summary of analysis of variance across different levels in university

\begin{tabular}{llllllllll}
\hline & \multicolumn{2}{l}{$\begin{array}{l}\text { Freshmen } \\
(\mathrm{n}=178)\end{array}$} & \multicolumn{2}{l}{$\begin{array}{l}\text { Sophomore } \\
(\mathrm{n}=164)\end{array}$} & \multicolumn{2}{l}{$\begin{array}{l}\text { Junior } \\
(\mathrm{n}=154)\end{array}$} & \multicolumn{2}{l}{$\begin{array}{l}\text { Senior } \\
(\mathrm{n}=137)\end{array}$} \\
\hline Dimension & $\mathrm{M}$ & $\mathrm{SD}$ & $\mathrm{M}$ & $\mathrm{SD}$ & $\mathrm{M}$ & $\mathrm{SD}$ & $\mathrm{M}$ & $\mathrm{SD}$ & $\mathrm{F}$ \\
\hline Truth-seeking & 3.94 & 8.49 & 4.17 & 7.96 & 3.92 & .733 & 4.02 & .84 & 1.21 \\
Open-mindedness & 4.18 & .91 & 4.42 & .77 & 4.17 & .80 & 4.33 & .78 & 1.25 \\
Analyticity & 4.49 & .70 & 4.36 & .82 & 4.48 & .71 & 4.61 & .77 & .75 \\
Systematicity & 4.49 & .77 & 4.50 & .77 & 4.39 & .78 & 4.44 & .67 & .24 \\
Critical thinking Self-confidence & 4.06 & .83 & 4.10 & .82 & 3.88 & .84 & 4.06 & .88 & .77 \\
Inquisitiveness & 4.67 & .69 & 4.62 & .75 & 4.42 & .75 & 4.56 & 1.02 & 1.20 \\
Cognitive maturity & 2.93 & .88 & 3.08 & .98 & 3.09 & .94 & 3.32 & 1.04 & 1.04 \\
Total & 4.13 & .42 & 4.20 & .44 & 4.06 & .48 & 4.20 & .47 & 1.10 \\
\hline & & & & & & & & & \\
\end{tabular}

\section{Conclusions}

\subsection{Critical Thinking and Gender}

It was found that the critical thinking disposition of Kasetsart university students had inconsistency with gender significantly. This result expressed unsurprisingly conclusion. It could possibly be explained by several supportive research studies. Korkmaz (2009) who proceeded studies on critical thinking level and dispositions of university students, Demirbag et al. (2016) who explored the comparison effect of an experimental program and the placebo effect on the improvement of critical thinking disposition of university students. The outcome demonstrated that there was no significant difference between critical thinking disposition towards gender. However, there were some previous research studies delivering different results. The similar conclusion was reached by Kucuk and Uzun (2013) who examined on teaching critical thinking tendencities of music teacher candidates. Also, Bakir (2014) who studied critical thinking disposition of pre-service teacher. Kartal (2012) and Sahin,; Tunca and Ulubey (2014) concluded that there was a significant difference based on gender in terms of total scores. The fact of the insignificant difference towards gender in most of the studies was congruent with the theoretical framework, whereas the reverse results reached by other scholars would be assumed concerning the sampling choices. Consequently, the findings retrieved are respectively consistent with the literature reviews and framework.

\subsection{Critical Thinking and Levels in University}

The levels of students were one of the variation that has been studied in order to investigate the tendency of critical thinking disposition. The findings revealed that critical thinking disposition of students had significantly disconnection with levels in university. The notion supported by Laird (2005) who evaluated critical thinking disposition scores of students from Michigan University, there was no significant difference between the groups based on levels in university. Another scholar, Lederer (2007), found that level in the program had not significantly affected on critical thinking dispositions. Further, Biber et al. (2013) and Kucuk and Uzun (2013) 
indicated that there were no statistical differences in critical thinking dispositions in agreement with the student grades.

\section{Limitations and Suggestions for Future Research}

Some inevitable limitations of the present study deserve attention. Firstly, participant selection may limit the generalizability of the results. One must be cautious when extending conclusions based on the results of this study. Future studies need to probe the critical thinking disposition of university students on the wide ranges of multi-perspectives (academic achievement, department, public society and culture, economics, etc.) Secondly, the reliability and validity of our instrument still leave room for enhancement. In particular, the reliability of truth-seeking and open-mindedness were low. Further research is needed to boost the reliability and validity of the questionnaires in order to improve the quality of the research. Lastly, it will be fruitful to supplement survey data with observation or focus group approach to enlarge the robustness of the results.

\section{References}

Abiogu, G. C., Ede, M. O., Agah, J. J., Ugwuozor, F. O., Nweke, M., Nwosu, N., ... Ugwuanyi, C. (2020). Cognitive-behavioural reflective training for improving critical thinking disposition of nursing students. Medicine (Baltimore), 99(46), 1-12. https://doi.org/10.1097/MD.0000000000022429

Bagheri, M., \& Nowrozi, R. A. (2015). A Comparative study of the critical thinking skills among the students of accounting and software in the female technical and vocational university in the city of Borojerd. Journal of Education and Practice, 6(13), 43-46. Retrieved from http://eric.ed.gov/?id=EJ1080601

Bakir, S. (2014). Critical Thinking Dispositions of Pre-Service Teachers. Educational Research and Reviews, 10(2), 225-233. https://doi.org/10.5897/ERR2014.2021

Biber, A. C., Tuna A., \& Incikabi, L. (2013). An Investigation of Critical Thinking Dispositions of Mathematics Teacher Candidates. Educational Research, 4(2), 109-117. Retrieved from https://www.scribd.com/document/342783833/Zul-5-an-Investigation-of-Critical-Thinking-Dispositions-ofMathematics-Teacher-Candidates

Bodi, S. (1988). Critical thinking and bibliographic instruction: the relationship. The Journal of Academic Librarianship, 14(3), 150-153. Retrieved from http://eric.ed.gov/?id=EJ376566

Boyaci, D. B., \& Atalay, N. (2016). A scale development for $21^{\text {st }}$ century skills of primary school students: A validity and reliability study. International Journal of Instruction, 9(1), 133-148. https://doi.org/10.12973/iji.2016.9111a

Crocker, L., \& Algina, J. (1986). Introduction to classical and modern test theory. Florida: Rinehart and Windston Inc.

Demirbag, B., Unisen, A., \& Yesilyurt, A. (2016). Training of critical thinking skills in teacher candidates and placebo effect: A quasi-experimental study. Eurasian Journal of Educational Research, 63, 375-392. https://doi.org/10.14689/ejer.2016.63.21

Ennis, R. H. (1985). A logical basis for measuring critical thinking skills. Educational Leadership, 43(2), 45-48. Retrieved from https://eric.ed.gov/?id=EJ327936

Ennis, R. H. (1996). Critical thinking dispositions: Their nature and assessability. Informal Logic, 18(2), 165-182. https://doi.org/10.22329/il.v18i2.2378

Facione, P. A. (1990). Critical Thinking: A Statement of Expert Consensus for Purposes of Educational Assessment and Instruction. Research Findings and Recommendations.

Facione, P. A. (2000). The Disposition toward Critical Thinking: Its Character, Measurement, and Relationship to Critical Thinking Skill. Informal Logic, 20(1), 150-153. https://doi.org/10.22329/il.v20i1.2254

Facione, P. A., \& Facione, N. (1992). The California Critical Thinking Disposition Inventory (CCTDI); and the CCTDI Test Manual. Millbrae, CA: California Academic Press.

Ghadi, I., Alwi, N. H., Bakar, K., A., \& Talib, O. (2012). Construct validity examination of critical thinking dispositions for undergraduate students in University Putra Malaysia. Higher Education Studies, 2(2), 138-145. https://doi.org/10.5539/hes.v2n2p138

Gellin, A. (2003). The effect of undergraduate student involvement on critical thinking: a meta-analysis of the literature 1991-2000. Journal of College Student Development, 44. 746-762.

https://doi.org/10.1353/csd.2003.0066 
Giancarlo, C. A., \& Facione, P. (2001). A look across four years at the disposition towards critical thinking among undergraduate students. The Journal of General Education, 50, 29-55. https://doi.org/10.1353/jge.2001.0004

Halpem, D. F. (1998). Teaching critical thinking for transfer across domains: Dispositions, skills, structure training, and metacognitive monitoring. American Psychologist, 53(4), 449-455. https://doi.org/10.1037/0003-066X.53.4.449

Ip, W., Lee D., Chau, J., Wooton, Y., \& Chang, A. (2000). Disposition toward critical thinking: A study of Chinese undergraduate nursing students. Journal of Advanced nursing, 32(1), 84-90. https://doi.org/10.1046/j.1365-2648.2000.01417.x

Khemmani, T. (2011). Analysis, synthesis, creative and critical thinking skills: Integration in teaching-learning plan. The Journal of the Royal Institute of Thailand, 36(2), 188-204. Retrieved from https://www.tci-thaijo.org/index.php/cmunursing/article/download/180710/128268

Khempet, N. (2018). The adaptation of the undergraduate freshmen in college of politics and governance, Mahasarakham University. Journal of politics and governance, 8(2), 186-199. Retrieved from https://so03.tci-thaijo.org/index.php/jopag/article/view/147208

Klaharn, R. (2014). The factors affecting the practicum achievement of the third - year nursing students of Srinakharinwirot university. Journal of The Royal Thai Army Nurses, 15(3), 412-420. Retrieved from https://he01.tci-thaijo.org/index.php/JRTAN/article/view/31308

Kucuk, D. P., \& Uzun, Y. B. (2013). Critical thinking tendencities of music teacher candidates. Ahi Evran University J. Kirsehir Educ. Faculty, 14(1), 327-345.

Laird, T. F. N. (2005). College students' experiences with diversity and their effects on academic self-confidence, social agency and disposition toward critical thinking. Research in Higher Education, 46(1), 365-387. https://doi.org/10.1007/s11162-005-2966-1

Lampert, N. (2006). Critical thinking dispositions as an outcome of art education. Studies in Art Education, 47(3), 215-228. https://doi.org/10.2307/25475782

Lazarus, A., \& Folkman, S. (1984). Stress, appraisal and coping. New York: Springer.

Ledere, J. M. (2007). Disposition toward critical thinking among occupational therapy students. The American Journal of Occupational Therapy, 61(5), 519-526. https://doi.org/10.5014/ajot.61.5.519

Lewin, K. (1935). A dynamic theory of personality: Selected papers. New York: McGraw-Hill.

Moore, T. (2013). Critical thinking: Seven definitions in search of a concept. Studies in Higher Education, 38, 506-522. https://doi.org/10.1080/03075079.2011.586995

Niyomtham, O., Thepmanee, M., \& Thongthai, V. (2017). The adjustment of students in rajamangala university of technology lannatak. Journal of Educatopn Research Faculty of Education, Srinakharinwirot University, 12(1), 273-285. Retrieved from http://ejournals.swu.ac.th/index.php/jre/article/view/9842/8382

Papp, K., Huang, C., Clabo, L., Delva, D., Fischer, M., Konopasek, L., Schwartzstein, M., \& Gusic, M. (2014). Milestones of critical thinking: A developmental model for medicine and nursing. Academic Medicine, 89(5), 715-720. https://doi.org/10.1097/ACM.0000000000000220

Poondej, C., \& Lerdpornkulrat, T. (2015). The Reliability and Construct Validity of the Critical Thinking Disposition Scale. Journal of Psychological and Educational Research, 23(1), 23-36. Retrieved from http://www.marianjournals.com/files/JPER_articles/JPER_23_1_2015/Poondej_Lerdpornkulrat_JPER_23_ $1 \_23 \_36 . p d f$

Poondej, C. (2012). Achievement Goal Orientation and the Critical Thinking Disposition of College Students across Academic Programmes (Unpublished doctoral dissertation). King Mongkut's University of Technology Thonburi. Thailand

Shute, V. J., \& Becker, B. J. (2010). Innovative assessment for the $21^{\text {st }}$ century. New York. NY: SpringerVerlag. https://doi.org/10.1007/978-1-4419-6530-1

Sirichat, W. (2007). The Relationships Between Critical Thinking Disposition, Coping Behavior, Self-efficacy and Assertive Behaviors of Chiang Mai University (Unpublished master thesis). Chiang Mai University. Thailand.

Taskesen, S. (2019). A study on art interests and critical thinking dispositions of students in fine arts department 
of the faculty of education. International Journal of Educational Methodology, 5(1), 275-287. https://doi.org/10.12973/ijem.5.1.275

Tirunehm, D. T., Verburgh, A., \& Elen, J. (2014). Effectiveness of critical thinking instruction in higher education: A systematic review of intervention studies. Higher Education Studies, 4(1), 1-17. http://dx.doi.org/10.5539/hes.v4nlpl

Velez, A. (2012). Preparing students for the future - $21^{\text {st }}$ century skills (Unpublished doctoral dissertation). University of Southern California.

Voronov, M., \& Singer, J. (2002). The myth of individualism-collectivism: A critical review. The Journal of Social Psychology, 142(4), 461-80. https://doi.org/10.1080/00224540209603912

Wang, X., Sun, X., Huang, T., He, R., Hao, W., \& Zhang, L. (2019). Development and validity of the critical thinking disposition inventory for Chinese medical college students (CTDI-M). BMC Medical Education, 19, 1-14. https://doi.org/10.1186/s12909-019-1593-z

Wangensteen, S., Johansson, S., Björkström, E., \& Nordström, G. (2010). Critical thinking dispositions among newly graduated nurses. Journal of Advanced Nursing, 66(10), 2170-2181.

https://doi.org/10.1111/j.1365-2648.2010.05282.x

Watson, G., \& Glaser E. M. (1980). Watson-Galser critical thinking appraisal manual. New York: Harcourt Brace and World.

Yeh, M.-L., \& Chen, H.-H. (2003). Comparison of affective dispositions toward critical thinking across Chinese and American baccalaureate nursing students. Journal of Nursing Research, 11, 39-46. https://doi.org/10.1097/01.JNR.0000347617.29413.96

\section{Copyrights}

Copyright for this article is retained by the author(s), with first publication rights granted to the journal.

This is an open-access article distributed under the terms and conditions of the Creative Commons Attribution license (http://creativecommons.org/licenses/by/4.0/). 